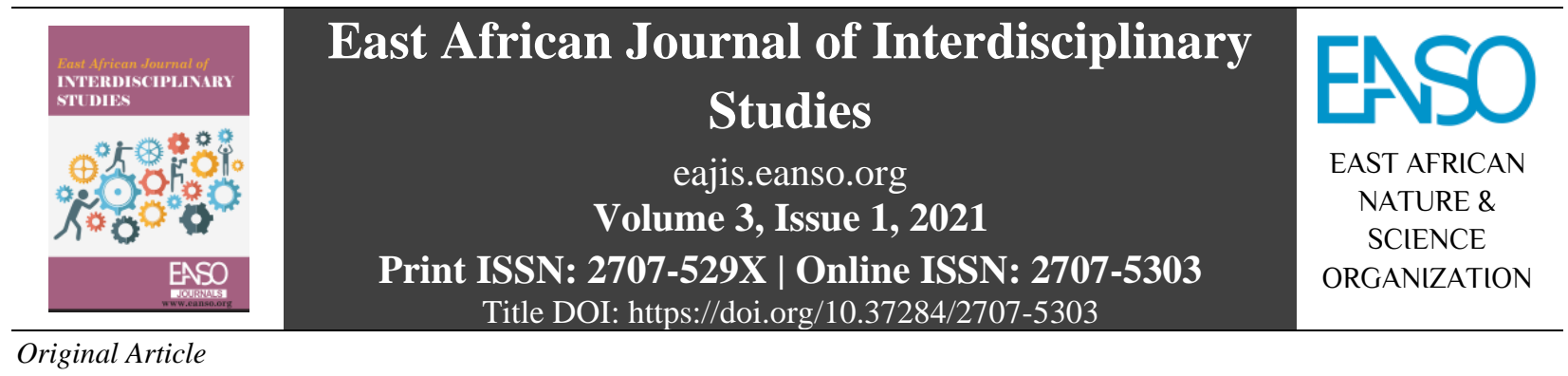

\title{
Repositioning Pan-Africanism for Human Security in the 21st Century
}

\author{
Mark Omorovie Ikeke, $P h D^{1 *}$
}

${ }^{1}$ Associate Professor, Department of Religious Studies and Philosophy Delta State University, PMB 1, Abraka Nigeria;

* ORCID: https://orcid.org/0000-0001-9115-378X. Author for Correspondence email: Ikeke7@ yahoo.com

Article DOI: https://doi.org/10.37284/eajis.3.1.372

\section{Date Published: ABSTRACT}

02 August 2021 Africa in the $21^{\text {st }}$ century is still troubled by myriads of problems. These problems include neo-colonialism, modern slavery, ethnicism, racism, xenophobic attacks,

Keywords: environmental degradation, human trafficking, sexual exploitation, war, famine, terrorism, conflicts, etc. All these problems gravely impede human security.

Pan-Africanism, Human security is more than military or national security and refers to all that Humanity, constitutes the good life and makes life more abundant for the people. Human Security securities include the access to food, portable water, education, good environment, 21 st Century, human rights, etc. Resolving and combating these problems will require concerted 21 st Century, efforts on the part of many if not all African nations in the continent and Diaspora.

Africa, Some of these problems cut across national boundaries. Problems like terrorism, Development. illegal migration, human trafficking, sexual exploitation, xenophobic attacks, etc cut across national borders. Though Pan-Africanism may have waned in strength it can be repositioned to harness African cultural and historic values to combat its contemporary problems in the $21^{\text {st }}$ century. A hermeneutic method will be used to interpret the meaning and import of Pan-Africanism and human security. A critical analytic method will be used to discuss the issues. The paper finds and concludes that Pan-Africanism can be re-positioned to enable Africa combat the problems facing her.

\section{APA CITATION}

Ikeke, M. O., (2021). Repositioning Pan-Africanism for Human Security in the 21st Century. East African Journal of Interdisciplinary Studies, 3(1), 151-161. https://doi.org/10.37284/eajis.3.1.372

\section{CHICAGO CITATION}

Ikeke, Mark Omorovie. 2021. "Repositioning Pan-Africanism for Human Security in the 21st Century". East African Journal of Interdisciplinary Studies 3 (1), 151-161. https://doi.org/10.37284/eajis.3.372.

\section{HARVARD CITATION}

Ikeke, M. O., (2021) "Repositioning Pan-Africanism for Human Security in the 21st Century", East African Journal of Interdisciplinary Studies, 3(1), pp. 151-161. doi: 10.37284/eajis.3.1.372.

\section{IEEE CITATION}

M. O. Ikeke, "Repositioning Pan-Africanism for Human Security in the 21st Century", EAJIS, vol. 3, no. 1, pp. 151-161, Aug. 2021. 


\section{MLA CITATION}

Ikeke, Mark Omorovie., "Repositioning Pan-Africanism for Human Security in the 21st Century". East African Journal of Interdisciplinary Studies, Vol. 3, no. 1, Aug. 2021, pp. 151-161, doi:10.37284/eajis.3.1.372.

\section{INTRODUCTION}

A grave challenge facing Africa is the issue of human security. Human security beyond the military security of the state implies the total wellbeing of the citizens of a nation. The African continent in this $21^{\text {st }}$ century is troubled by evils such as global terrorism, human trafficking, wars, famine, environmental degradation, electoral fraud, violent conflicts, poverty, ethnicism, racism, xenophobic attacks, illegal migration, kidnapping, and so forth. These problems impede human security. Some of these problems such as atmospheric and marine pollution, human trafficking, illegal migration, violent conflicts, and xenophobic attacks require more than the efforts of one nation to combat. These problems mentioned begin in one nation and affect other nations. Take for instance when gas is flared in the Niger Delta of Nigeria the effects reach the atmosphere in places like Cameroon, Togo, Equatorial Guinea, etc. Boko Haram terrorism in Nigeria has equally affected countries like Niger, Chad, Cameroon, etc.

In combating these transnational crimes and problems, Pan-Africanism has a role to play. What affects one African country affects others also. This is why Africans and African countries both in continental Africa and the Diaspora should show solidarity for one another in combating these problems. It is true that in the height of the struggle against colonialism, slavery, Apartheid, racism, and many other evils perpetrated against black people Pan-Africanism was a serious cultural and political movement that worked for the liberation and freedom of African peoples. With many of those issues abated Pan-Africanism waned in strength. This notwithstanding Pan-Africanism can still be repositioned to combat contemporary problems facing African countries and people of African descent.

\section{Analysis of Concepts}

What is Pan-Africanism? For the American Historical Association (2018) citing the African World Supplement: 'Pan-Africanism was the attempt to create a sense of brotherhood and collaboration among all people of African descent whether they lived inside or outside of Africa' (par. 2). Makalani (2011) indicates that Pan-Africanism is a complex phenomenon embracing black intellectual and political thought over the last 200 years and could be inclusive of political, ideological, cultural issues; though basically, it is the idea that black people have a common historical destiny (par 1). Some forms of Pan-Africanism call for the political unity of Africa into a united Africa. Falola \& Agbo (2019) say it is the movement of western-educated Africans who questioned discriminatory and racial prejudices of white people, and colonial domination of the African continent and so they struggled for and had the continent decolonized, and also the improvement in the situations of Africans in the Diaspora. Despite the difficulty in defining Pan-Africanism, Matera (2019) says: 'Pan-Africanist intellectual, cultural, and political movements tend to view all Africans and descendants of Africans as belonging to a single "race" and sharing cultural unity.' (par. 1).

Bakut (2010) citing T.A. Imobighe says that security is the 'elimination of threats to one's ecosystem, socio-cultural values, as well as the political and economic structures' (p. 92). There is also the national-statist definition of security which is considered to be of the traditionalist school. Eselebor (2012) says that for the traditionalist schools rooted in a cold war mentality, security is the military defence of the state from external aggression; while the non-traditionalists see it as including environmental, economic, social, feminist issues. The traditional position privileges the territorial integrity of the state, its sovereignty. Essien (2012) also corroborates this twofold understanding of security by stating that security was understood to mean the state protecting its internal and external interests and maintaining order. But he notes that this perspective has been challenged as outdated as after the cold war there are non-military threats like inequality, poverty, human rights abuses, environmental degradation, etc that make people insecure. And so Essien (2012) rightly argues that beyond military equipment, 
security embraces good governance, elimination of poverty, provision of employment, the establishment of peace, provision of food.

The idea of human security arose to assert that security needs to be seen holistically and not just in terms of military security of the state from aggression. Security is inclusive of the needs of the people being met by the government and their living an optimal life. Gregoratti (2018) propounds that as against traditional orthodox definitions of security that privileges the state, human security is concerned with the individual wellbeing in combating deprivations such as poverty, disease, etc that equally undermine peace and impede human welfare. United Nations Development Programme (1994) says human security deals with the value and preservation of the dignity of human life, including 'freedom from fear' and 'freedom from want.' Tieku (2007) says: 'Human security, defined as the protection of people and communities, rather than of states, from violence and imminent danger, has become a central feature of the contemporary international order' (p.27).

\section{LITERATURE REVIEW}

Kuryla (2016) essentially traces the history of PanAfricanism. South African History Online (2019) also traces the history of Pan-Africanism. In Goodridge (2006) the attention is on examination of the Commission for Pan-African Affairs established by the country of Barbados and how it is aiding PanAfricanism and African integration. The paper covers the African factor in the Barbados experience, the origin of the commission and its goal of establishing Caribbean African links with socio-cultural, economic and political engagements.

Nwikina (2017) discusses the continuous relevance of Pan-Africanism. He argues that though the context of slavery and European oppression in which Pan-African prevailed in the past has changed it is still relevant in working to promote connections and integration in Africa. For Falola \& Agbo (2019) not much has been done on $21^{\text {st }}$ Century appraisal of Pan-Africanism. Maimela (2013) argues for a reassertion of Pan-Africanism to face the $21^{\text {st }}$-Century challenges confronting Africa. The attention of Tieku (2007) is on asserting that African Union is concerned with human security issues as they are integrated into her documents, though the ruling elite find it difficult to implement. Poku, Renwick and Porto (2007) devote their piece to discussing the development challenges and human insecurities plaguing the continent such as violence, civil wars, unstable governments, etc. Holliday and Howe (2011) discuss how the concept of security has transformed from the traditional understanding to include freedom from wants, deprivations, and how it now implies a global responsibility to protect and provide for those in need, especially in global emergencies. Badejo (2007) is concerned with the role of Africana women in Africana studies and the need for women to reclaim their educative and cultural role of fostering communal wellbeing. The dimension tackled by Bakut (2010) is on the global security threats to African security. Eselebor (2012) distinguishes between traditional and nontraditional understanding of security, while at the same time examining the security threats in nationstates without borders. Dokubo (2010) discusses how to use international relations to enhance 'national security interest' of Nigeria (p.25). He also discusses the causes of instability such as political intolerance, religious fundamentalism, natural resources mismanagement, smuggling, and proposes Nigeria should synergize with other nations to overcome these problems.

A critical search through the literature on PanAfricanism and Security shows a rich body of literature. Many of them show the continuous relevance of Pan-Africanism and how it can be reenergised to combat African problems. The literature on security clearly reveals the two traditions of understanding security and shows the various threats to security. There is rarely a discussion of the two issues of Pan-Africanism and Security together as this paper will discuss it. There is also the fact that human security is noticeably not discussed from the perspective that there is a moral obligation for Pan-Africanist to champion it. The uniqueness of this paper is that it proposes that there is a moral obligation to promote human security in Africa through Pan-Africanism.

\section{History and Task of Pan-Africanism}

The history of Pan-Africanism depends on what definition you give to Pan-Africanism. While some 
scholars trace it back to 1791, others think it began in the early part of the $20^{\text {th }}$ century. Surhone, Timpledon and Marseken (2010) citing Wikipedia sources aver that towards the end of the $18^{\text {th }}$ century there were many slave revolts and there developed a political movement across Africa, the Americas, and Europe to stop oppression of African people. For instance, these authors just mentioned show that Sons of Africa was a political group in London that met, did letter-writing, visited parliament calling for an end to black oppression. In their letter-writing as these authors note, the people they wrote to included Granville Sharp, King George III, William Pitt, the Prince of Wales (who became George IV), and other White abolitionists. These authors state further that information about this group is noted by Quobna Ottobah Cugoano. Nwikina (2017) citing Cheikh Anta Diop avers that Pan-Africanism predates the modern ideology called Pan-Africanism for African kingdoms like Ghana, Egypt, Mali, Kush, Songhai, Libya, Ghana, did engage one another.

What could be called modern Pan-Africanism can be dated to the middle of the $19^{\text {th }}$ century. Kuryla (2016) names some prominent figures and their ideas in the Pan-Africanist struggle for the emancipation of Africans. The figures he mentions include: Alexander Crummel, Martin Delany, Edward Blyden, W. E. B. Du Bois, Marcus Garvey, CLR James, George Padmore, Leopold Senghor, Aime Cesaire, Jomo Kenyata. Kwame Nkrumah, Molete Asante, Cheikh Anta Diop, Carter G Woodson, and Maulana Ron Karenga. He equally mentions the Pan-African Congress as part of the history of Pan-Africanism. Kuryla (2016) notes the ideas and actions associated with the above names as follows: (1) Delany and Crummel who were African Americans and Blyden a West Indian focused on the connections between blacks in continental Africa and in the United States; (2) Delany advocated black people create their own nation as they cannot truly prosper alongside Whites, (3) Crummel and Blyden proposed that black people should return back to continental Africa; (3) W. E. B. Du Bois (considered the true father of Pan-Africanism by some) during the early $20^{\text {th }}$ century advocated against racism, European colonialism in the African continent, and pushed for the study of African cultural history; (4) the Jamaican-born black nationalist, Marcus Garvey in early 1900s pushed for African independence and highlighted the positive attributes of African peoples and culture through his Universal Negro Improvement Association (UNIA). The following persons: CLR James in the 1920s to 1940s, Jomo Kenyata, Senghor, and Ceisare were equally strong advocates of Pan-Africanist ideas as Kuryla (2016) notes. Nkrumah another strong advocate of PanAfricanism actually called for a politically united Africa and fought zealously for the independence of African countries from European colonialism. It was Nkrumah who led his country to independence in 1957.

As stated by Kuryla (2016) in the 1940s due to the fact that many Pan-Africanists were sympathetic to communist ideas, the movement waned in the United States (as communist ideas were fought against) making African intellectuals come to lead the Pan-Africanist movement. To be considered also as part of the history of Pan-Africanism is the Afrocentric movement from the 1960s led by Molete Asante. Diop of Senegal, Woodson and Karenga are also forces in the Afrocentric movement. Outside the Pan-African meeting held in London in 1900, the following Pan-African Congress held in 1919, 1921, 1923, 1927, 1945 and 1974 have all contributed to the Pan-Africanist struggle.

The Organisation of African Unity in 1963, now the African Union could be seen as a successor of all preceding Pan-Africanist ideas and struggles. In this $21^{\text {st }}$ century, Pan-Africanism has been greatly weakened. Today African countries have gained independence from European colonialists and African Americans have been emancipated from slavery and have obtained some measures of human and civil rights; even though racism is still present in the states (but not officially). Chegg Study (2019) avers that since they have gained independence they are now embroiled in competing national interests. The Pan-Africanism idea was given great emphasis as Africans struggled against European colonialisms in the $19^{\text {th }}$ and $20^{\text {th }}$ Centuries.

The question that arises then is can Pan-Africanism still be relevant today considering that it arose within a different social and cultural context? The Pan-Africanist idea and practice arose within a different cultural context, but the basic core of PanAfricanism that people of African descent have 
common values, destiny, shared experience and should bond together remains true. Africa and her Diaspora people are still plagued by myriads of social, political, economic, and cultural challenges. As noted previously many of these problems are transnational and cannot be solved by only one nation. The Pan-Africanist idea is still relevant today more than ever. In 2004 as Goodridge (2006) notes, the country of Barbados established a Commission for Pan-African Affairs with the responsibility of promoting cultural, social, and development linkages between Barbados and continental Africa. The point made by Goodridge (2006) should not be glossed over. He opined thus: "The African Union now represents the highest stage of Pan-Africanism and is correcting some of the deficiencies of its predecessor the Organisation of African Unity" (p. 53). Goodridge (2006) notes that the OAU focused on intergovernmental cooperation in the African continent to the neglect of the Diaspora and Non-Governmental Organization. With the focus of the African Union, he notes that the ideas and goals of visionaries like Padmore, Garvey and Nkrumah could be achieved.

\section{Human Insecurities in Africa}

There are human security challenges all over the African continent. The Harvard Kennedy School Carr Center for Human Rights Policy (2019) states that: 'Major global threats to human security include war, mass atrocities, environmental degradation, and public health crises. Some human security issues are well known, like torture and genocide, and others are hidden, like the millions of missing women in the world. Refugees, the stateless, and those who live in failed states are often the most vulnerable' (par 1). The United Nations indicates economic, food, health, environmental, personal, community, and political securities as human security challenges. Some of these threats are taking place in Africa. In the recent past African countries like Liberia, Sierra Leone, Sudan, Ethiopia, etc have experienced wars. There are still violent conflicts taking place in the Democratic Republic of Congo, the Horn of Africa, etc. Wars have caused the dislocation of lives and properties. It has shattered people's dreams and disorganized communities and broken homes. It has turned people into environmental refugees, etc. Indeed, it has made the lives of people insecure. The Nigerian
Civil War took thousands of lives and destroyed properties. In the Rwanda genocide, almost a million people were killed. Environmental degradation is another problem that has caused human insecurities in the continent. In Nigeria's Niger Delta oil exploration ad caused atmospheric and marine pollution that has destroyed farmlands, rivers and destroyed people's source of livelihood. In Nigeria's Niger Delta lives have been made insecure. Amnesty International, Human Rights Watch, the United Nations all show how oil multinational companies have destroyed peoples' lives and cultures. Bad governance and poor leadership all over the continent have led to massive underdevelopment in infrastructure, unemployment, corruption and embezzlement of public funds, and turned thousands of African youths into illegal migrants. And many have died in the Mediterranean Sea. It is painful to note that Africa is a land of human miseries and agonies.

\section{Pan-Africanism and the Moral Obligation to Mitigate Human Insecurities}

The Pan-Africanist idea is still relevant. It does not have to be called Pan-Africanism. The whole idea of the founding of the Organization of African Unity in 1963 and then its mutation into the African Union in 2002 is to propagate the shared African experience and values and promote African solidarity and transnational cooperation. The organization was founded on Pan-Africanist ideas.

The challenge is that since modern Pan-Africanism arose within the context of the struggle against slavery and European colonialism, is it still relevant to the contemporary context. Nwikina (2017) states that even though the context in which PanAfricanism existed in the past is no longer the same as today, he argues forcefully that it can act as a force to integrate and connect Africans. This integration and connection can help Africans mobilise to combat human insecurities in the continent. The just mentioned author avers that: 'we must learn important lessons from the first phase of Pan-Africanism; as the relevance of Pan-Africanism today must be to reinforce the links between our states by establishing and strengthening common institutions, harnessing the human capital by integrating the continent and providing avenues for Intra-African trade'. Ekekwe (2017) writes that 
Pan-Africanism should help improve seamless relationships among Africans and foster trade and development.

Beyond Pan-Africanism today helping in fostering integration and connections in African and to the Diaspora, it should help to combat the human insecurities in Africa and the Diaspora world. Africa in the past was troubled by the transatlantic slave trade and European colonialism; today it is troubled by other ills such as neo-colonialism, modern forms of slavery, terrorism, human trafficking, etc. Concerted efforts have to be made by the African Union, regional organizations in the continents such as ECOWAS, non-governmental organisations, and Diaspora associations to take actions to combat these problems. Some African countries already have Diaspora commissions such as Nigeria. Their duties should not just be to promote trade but cultural and moral values of African people that can be used to combat social ills.

Xenophobic attacks and violence which are becoming more rampant in South Africa and other African countries greatly impede human security. It destroys the bond and harmony between individuals, social groups and nations. People have been killed. Some have had their sources of income destroyed and are now subjected to human and starvation. In the midst of all these social turmoil and problems that impede human security, PanAfricanism and the Pan-Africanist idea are very relevant. African has common moral and cultural values such as hospitality, generosity to strangers, Ubuntu, etc that should be fostered more than ever before. The Organization of African Unity (1981) African Charter on Human and Peoples Rights noted the imperative of African values.

It can be averred frontally that the purpose of the Organization of African Unity, now AU is to secure the human life and wellbeing of all Africans and foster harmony with other nations. African Development Bank, the African Court on Human and People's Rights, the African Court of Justice, etc are aimed at this. There is no reason why agencies of the AU should not work to enhance human security in the continent and beyond to justify the reason that they exist.

Maimela (2013) argues for moving from a statist Pan-Africanism which is often weak and fractured.
Maimela (2013) cites Muchie, Habib and Padayachee who argue for a shift from a statist panAfricanism to a "democratisation of African integration". These three authors according to Maimela (2013) state that the participation of civil society in the Pan-African agenda helps to promote human rights and critique bad leadership.

There is need for a Pan-Africanism that is also led from below. Against the background of the organization of the African Union privileging the statist position and national sovereignty, Tieku (2007) writes that the new generation of PanAfricanists like President Nelson Mandela, Ahmed Salim, etc argued for the need for Pan-Africanism to be concerned about the needs facing Africans today. In the past Pan-Africanists fought against racial injustice and civil, human and political rights for Africans. Today African people are still living under various forms of oppression. All through the continent Africans are living under poor and bad governance that has failed to secure their welfare and wellbeing. In the recent past protests have taken place in Algeria, Tunisia, Egypt, against poor governance. King did say that we all are tied in an inescapable network of mutuality, whatever happens to one happens to all, and injustice anywhere is a threat to justice everywhere. Individuals and groups all over the continent and beyond need to bond in solidarity to tackle these problems. The African Union Commission (2015) clearly asserts her Pan-African roots and heritage and the necessity of Pan-Africanism today when she affirms thus:

We, the people of Africa and her Diaspora, united in diversity, young and old, men and women, girls and boys from all walks of life, deeply conscious of history, express our deep appreciation to all generations of PanAfricanists. In particular, to the founders of the Organisation of African Unity for having bequeathed us an Africa with exemplary successes in the fight against slavery, colonialism and apartheid. Agenda 2063, rooted in Pan Africanism and African Renaissance, provides a robust framework for addressing past injustices and the realisation of the 21st Century as the African Century. (p. 1) 
The African Union Commission in Agenda 2063 states forthrightly the goals of the African that is needed:

1. A prosperous Africa based on inclusive growth and sustainable development 2. An integrated continent politically united and based on the ideals of Pan-Africanism and the vision of Africa's Renaissance 3. An Africa of good governance, democracy, respect for human rights, justice and the rule of law 4. A peaceful and secure Africa 5. An Africa with a strong cultural identity, common heritage, shared values and ethics 6. An Africa whose development is people-driven, relying on the potential of African people, especially its women and youth, and caring for children 7. Africa as a strong, united and influential global player and partner. (p. 2)

A central argument of this paper is that working and promoting human security issues and value to provide a better and optimal life for Africans in the continent and people of African descent on the part of the African Union, Civil Societies Organizations and others is a moral obligation. What makes it moral is that it is the right thing to do. The health, wellbeing, welfare, and wellness of people are what ethics and morality foster. The goal of political and social institutions is to provide a good life for the people. Aristotle affirms the goal of governance is good life and happiness for the people. In Kantian ethics, the priority is on treating the human being as an end in itself. The philosophy of personalism affirms treating human beings not as machines or means but people with dignity, worth and value. In both John Locke and Jean Jack Rousseau's notion of the social contract, the state or society came into existence for protecting the rights and welfare of the people. The individuals and peoples in their communities enjoying peace, harmony, health, freedom from all fears and harms are crucial to the existence of society. The American Declaration of Independence affirms that all human persons are entitled to life, liberty, and the pursuit of happiness. United Nations (1948) enunciates that: "everyone has the right to life, liberty and security of person" (art 3). This right that the human person has imposes duties and obligations on states and others to ensure they are guaranteed. This paper affirms that the movement of Pan-Africanism in which Africans and people of African descent cooperate and collaborate has a role to play in ensuring that the right to life, liberty and security of the person is respected. PanAfricanism stood and galvanised peoples and societies in the past to work for the rights of Africans to be free from European colonialism, racial discrimination and promoted their economic wellbeing. The new Pan-Africanists and PanAfricanist instruments like the African Union and Civil Societies all over the continent and the African Diaspora cannot abandon this mission of working for the wellbeing of Africans now. As the paper has noted there are African problems that are transnational and cannot be solved by one nation alone. Human trafficking, atmospheric pollution, climate change, terrorism cut across one nation. The Boko Haram problem in Nigeria is equally affecting neighbouring countries like Cameroon, Chad, Niger, etc. This is why they have come together to tackle it collectively through joint security initiatives. The establishment of the Economic Community of West African States, Southern African Development Community (SADC), etc also shows that these nations know that they need joint and concerted efforts to develop and walk for the wellbeing of their people.

The moral obligations to ensure that individuals are humanely secured from all that harms and deprive them of the good and optimal life of happiness are not only that of the state or government. There is a human right to security. This security is inclusive of human security as now understood without which every other form of security is meaningless. The human right to security is evident from international, regional, and national human rights instruments and documents. Federal Republic of Nigeria (1999) says that: 'the security and welfare of the people shall be the primary purpose of government' (art 14b). Since this is the objective of the government, them the people are entitled to it from the government. The Organization of Africa unity (1981) says, 'Every individual shall have the right to liberty and to the security of his person...' (art 6). The United Nations (1948) says: 'Everyone has the right to life, liberty and security of person' (art 3). The United Nations state that: 'All individuals, in particularly vulnerable people, are entitled to freedom from fear and freedom from want, with an equal opportunity to enjoy all their rights and fully develop their human potential.' 
Human security and every other form of security that fosters the wellbeing and welfare of individuals and ensures that they are protected from all deprivations in order to enjoy the good life is a human right. 'Security,' also as Nwolise (2018) states 'remains a sacred value, for all times, individuals, groups, and nations, it is the utmost value. This arises from the incontrovertible truth that one must be alive for any other value to be meaningful' (p. 142). Security is crucial to human wellbeing and is necessarily a human right. A Right places obligations on other parties to ensure that it is fulfilled. The worth and value of the human person or individual implies that his inviolable dignity is preserved and promoted. That is a key reason for human rights declarations.

Guaranteeing the rights of persons who secure their lives is not only that of government but also that of non-state actors such as individuals and civil society organizations. The African Union Commission (2015) clearly states that among the critical enablers of the transformation of African and the promotion of Agenda 2063 are: 'The People's ownership and mobilisation: The continuous mobilisation of the African people and the Diaspora in various formations, effective communication and outreach, and sustained and inclusive social dialogue on Agenda 2063' (p. 19). There is need for serious synergy in fostering human security for all African people. This can be done through continuous educational exchanges, cultural festivals, dialogues, meetings, etc. The reality is that Pan-Africanism is not dead. It only needs to be re-driven with more vigour than ever before to combat present African human insecurities challenges. It is important for all individuals, civil society organizations, nongovernmental organizations in the African continent and in the Diaspora not to wait on the governments of the continent but to equally on their own network, interlink, expand social and cultural exchanges to strengthen ties between Africans in the continent and in the Diaspora with the aim to collectively combating African challenges of insecurities. There is a need for more conferences, symposia, workshops, educational tours and other critical events to be organized among Africans to pressure their governments and leaders for good governance and resolving the human insecurities in the continent. It is important to note that in discussing the question of moral obligation there are those who feel that obligations are only to those within the same closed community or nation-state. Young (2007) cites Rawls in The Law of Peoples, and David Miller who are of this view. Young (2007) certainly disagrees with these scholars asserting that the logic of social connection implies that those who participate and cause structural injustice bear a responsibility in acting to end it in an interconnected world. As for combating human insecurities in Africa, this paper argues that African cultural and moral values such as Ubuntu, Ujamaa, African humanism grounds it. Africans see themselves as kinsmen and whatever happens to one happens to all. You don't have to partake in causing harm or injustice before you can act. The project of PanAfricanism should be grounded in African ethics of communalism, personhood, Ubuntu, etc and not on the western understanding of justice; though it can draw insights from other traditions.

This is a moral obligation that should not be overlooked. African values like Ubuntu, Ujamaa, African humanism, etc all ground these partnerships. There is a strong African cultural basis for Pan-Africanism. Another important instrument vital for propagating the Pan-African consciousness for mental emancipation of Africans is the teaching of Pan-African history both in Africa and the Diaspora. It was to highlight this fact that the Center for Black and African Arts and Civilization, Federal Ministry of Tourism and Culture, and National Orientation Nigeria (2008) organised an international conference tagged: 'Teaching and Propagating African History and Teaching Diaspora History and Culture to Africa.'

It ought to be borne in mind that the Pan-Africanist call is not a call for Africa to isolate herself from the rest of the world, rather it is for her to harness her cultural and moral values, experience, and advantage to engage and interact with the rest of the world. Just as the European Union, the Non-Aligned Movement, the G7, Organization of American States, etc are not isolationist so the call for concerted Pan-Africanism does not imply isolationism. Tom Mboya as cited by Makumba (2007) correctly notes that Pan-Africanism should not create an inward-looking, isolated African society but one that is open to the universal and world culture from its own deepest roots. 


\section{CONCLUSION}

The paper has argued forthrightly that PanAfricanism is still very relevant in the $21^{\text {st }}$ century to Africa and her Diaspora. The paper had after the introduction made some conceptual analysis in which terms like Pan-Africanism and human security were examined. It then did a literature review of these two concepts. The literature review revealed that the two issues of Pan-Africanism and human security had not been treated from a moral or ethical perspective. The paper looked at the history of Pan-Africanism and equally presented some of the human insecurities in the continent. The paper then argued for the relevance of PanAfricanism and asserted that it is a moral obligation for Pan-Africanism to work to abate the social ills and insecurities in Africa. The paper also revealed that African cultural values such as Ubuntu, Ujamaa, African humanism and hospitality to strangers can help in promoting this new PanAfricanism to ameliorate human insecurities in Africa. The paper concludes by affirming that PanAfricanism is still relevant and needs to be repositioned for more relevance in Africa today.

\section{REFERENCES}

African Union Commission. (2015). Agenda 2063: The Africa We want. Retrieved October 20, 2019, from https://www.un.org/en/africa/osaa/p df/au/agenda2063.pdf

American Historical Association. (2018). The PanAfrican Movement. Retrieved 10 October, 2019, from https://www.historians.org/teaching-andlearning/teaching- resources- for historians/teac hing-and-learning-in-the-digital-age/throughthe-lens-of-history-biafra-nigeria-the-west-andthe-world/the-colonial-and-pre-colonial-eras-innigeria/the-pan-african-movement

Badejo, D. L. (2007). Gender ideology, global Africa, and the challenge for Pan-Africanism and Pan-African studies in the $21^{\text {st }}$ century. In Tunde Babawale (Ed.), The place of research and studies in the development of Africa and the African Diaspora (p.279-317). Lagos: Concept Publications Limited.
Bakut, B. T. (2010). Global threats and Africa's security: Is Africa relevant? Nigerian Journal of International Affairs, 36(1), 91-111.

Center for Black and African Arts and Civilization, Federal Ministry of Tourism and Culture,and National Orientation Nigeria. (2008). Teaching and propagating African History and teaching Diaspora History and culture to Africa. Lagos: Concept Publications Limited.

Chegg Study. (2019). Pan-Africanism. Retrieved October 20, 2019, from https://www.chegg.com/homeworkhelp/definitions/pan-africanism-47

Dokubo, C. (2010). Enhancing Nigeria's national security interest through International Relations. Nigerian Journal of International Affairs, 36(1), 25-44.

Ekekwe, N. (2017). Tekedia, 1 7. Retrieved October 20 , 2019 , from http://tekedia.com/65650/comprehensivevaluations-of-nigerian-tech- startups/.

Eselebor, W. A. (2012). Deconstructing security in nation-states without borders. In IsaacOlawale Albert, Willie Aziegbe Eselebor (Ed.), Peace, security and development in Nigeria (pp. 297315). Abuja: Society for Peace Studies and Practice.

Essien, F. (2012). Management of security threats in Nigeria: An integrative approach. In Isaac Olawale Albert, Willie Aziegbe Eselebor (Ed.), Peace, security and development in Nigeria (pp. 435-461). Abuja: Society for Peace Studies and Practice.

Falola, T., \& Agbo, C. (2019). The Prospects and challenges of Pan-Africanism. Oxford Research Encyclopedia of Politics. Retrieved October 29, 2019, from https://oxfordre.com/politics/view/10.1093/acre fore/9780190228637.001.0001/acrefore9780190228637-e-718

Federal Republic of Nigeria. (1999). Constitution of the Federal Republic of Nigeria. Retrieved October 20, 2019, from http://www.nigeria- 
law.org/ConstitutionOfTheFederalRepubli cOfNigeria.htm

Goodridge, R. A. (2006). Pan-Africanism and (African) integration: The case of the Commission for Pan-African Affairs in Barbados. In R.T. Akinyele (Ed.), African integration: Images and perspectives (p. 33-69). Lagos: University of Lagos Press.

Gregoratti, C. (2016). Human security. Retrieved October 20, 2019, from https://www.britannica .com/topic/human-security.

Harvard Kennedy School Carr Center for Human Rights Policy. (2019). Human security. Retrieved October 20, 2019, from https://carrcenter.hks.harvard.edu/humansecurity

Holliday, I., and Howe, B. (2011). Human security: A global responsibility to protect and provide. The Korean Journal of Defense Analysis, 23 (1): 73-91. Retrieved October 20, 2019, from file:///C:/Users/ADMIN/Downloads/Human_Se curity_A_Global_Responsibility_to_Protect_pp df

Kuryla, P. (2016). Pan-Africanism. Retrieved October 19, 2019, From https://www.britannica.com/topic/Pan-

Africanism.

Maimela, D. (2013). Pan-Africanism of the 21st century - Challenges and prospects. The Journal of the Helen Suzman Foundation, 71, 34-39. Retrieved October 20, 2019, from https://hsf.org.za/publications/focus/copy_of_fo cus-71-state-nation/pan-africanism-of-21stcentury-d-maimela.pdf

Makalani, M. (2011). Pan-Africanism. Retrieved October 20, 2019, from http://exhibitions.nypl.org/africanaage/essaypan-africanism.html

Makumba, M. M. (2007). Introduction to African Philosophy. Nairobi: Pauline Publications Africa.

Matera, M. (2019). Pan-Africanism. New dictionary of the history of ideas. Retrieved October 27, 2019 from Encyclopedia.com: https://www.encyclopedia.com/history/dictionar ies-thesauruses-pictures-and-press-releases/panafricanism

Nwikina, E. B. (2017). Pan-Africanism: Its relevance today. Retrieved October 20, 2019, from

https://medium.com/@eugenebanigonwikina/pa n-africanism-its-relevance-today-7db0fccc4c 25

Nwolise, O. B. C. (2018). Security challenges, peace building and nation-building in Nigeria. In Emeka Anthony Obi \& Ikenna Mike Alumona (Ed.), Introduction to peace and conflict studies: Security challenges and peace building in Nigeria (pp. 142-170). Onitsha: Bookpoint Educational Limited.

Organisation of African Unity. (1981). African Charter on Human and Peoples Rights. Retrieved October 20, 2019, from http://www.humanrights.se/wpcontent/uploads/ 2012/01/African-Charter-on-Human-andPeoples-Rights.pdf

Poku, N.k., N. Renwick \& Portu, J.G. (2007). Human security and development in Africa. International Affairs 83 (6): 1155-1171. Retrieved October 20, 2019, from https://www.jstor.org/stable/4541916?seq=1\#pa ge_scan_tab_contents

South African History Online. (2019). PanAfricanism. Retrieved October 19, 2019, from https://www.sahistory.org.za/article/panafricanism.

Surhone, L. M., Timpledon, M.T., \& Marseken. (Ed.). (2010). Pan-Africanism: Sociopolitical, worldview, philosophy, Native Africans, Africa, European slave trade. Beau Bassin, Mauritius: Betascript Publishing.

Tieku, T. K. (2007). African Union promotion of human security in Africa. African Security ,16(2), 26-37. Retrieved October 15, 2019, from.file:///C:/Users/ADMIN/Downloads/Afric an_Union_promotion_of_human_security_in_A fric.pdf

United Nations Development Programme. (1994). Human development report 1994. Retrieved 
East African Journal of Interdisciplinary Studies, Volume 3, Issue 1, 2021

Article DOI: https://doi.org/10.37284/eajis.3.1.372

November $\quad$ 4, 2019, from http://hdr.undp.org/sites/default/files/reports/25

5/hdr_1994_en_complete_nostats.pdf

United Nations. (1948). Universal Declaration on Human Rights. Retrieved October 20, 2019, from https://www.un.org/en/universaldeclaration-human-rights/.

161| This work is licensed under a Creative Commons Attribution 4.0 International License. 